\title{
Mortality and disease severity among COVID-19 patients with hypertension receiving renin-angiotensin system inhibitors
}

\author{
Syed Shahzad Hasan ${ }^{1}$, Chia Siang Kow ${ }^{2}$, and Hamid Merchant ${ }^{1}$ \\ ${ }^{1}$ University of Huddersfield \\ ${ }^{2}$ International Medical University
}

May 6, 2020

\begin{abstract}
The use of renin-angiotensin system (RAS) inhibitors, including angiotensin-converting enzyme inhibitors (ACEIs) and angiotensin receptor blockers (ARBs), is alleged to cause a more severe course of novel coronavirus disease 2019 (COVID-19). We systematically reviewed the available studies to assess the association of RAS inhibitors with mortality as well as disease severity in COVID-19 patients. A systematic literature search was performed to retrieve relevant original studies investigating mortality and severity (critical disease) in COVID-19 patients with and without exposure to ACEIs/ARBs. A total of 13 original studies were included; 11 studies reporting on mortality and 10 studies reporting on disease severity in ACEI/ARB exposed and unexposed groups. Among hypertensive COVID-19 patients, the use of ACEI/ARB was associated with a significant reduction in the risk of mortality exhibiting a pooled relative risk of 0.73 (95\% confidence interval: $0.63-0.86)$. Moreover, there was no significant difference in the risk of developing severe/critical COVID-19 disease between ACEI/ARB and non-ACEI/ARB groups showing relative risk of 0.72 (95\% confidence interval: 0.46-1.12). The data indicate that the use of ACEI/ARB was associated with reduced risk of mortality in COVID-19 patients taking these medications to manage their hypertension.
\end{abstract}

\section{INTRODUCTION}

Observational studies [1-3] on patients with novel coronavirus disease 2019 (COVID-19) tend to favour an association of hypertension with COVID-19, in which hypertension has been the most frequently identified comorbidity. Besides, the presence of hypertension tends to portend a more severe course of COVID-19 [1-3]. Some researchers were quick to link such association on the use of renin-angiotensin system (RAS) inhibitors, including angiotensin-converting enzyme inhibitors (ACEIs) and angiotensin receptor blockers (ARBs), among hypertensive patients [4]. The issue has since rapidly escalated to hot debate among the medical community.

The SARS-CoV-2, the causative agent for COVID-19, binds to the ACE2 receptor on host cells to gain entry [5]. In several animal models and human studies, the expression of ACE2 is increased with the administration of RAS inhibitors, which suggests a possible increased susceptibility to SARS-CoV-2 with the use of RAS inhibitors [6-8].

On the other side of the debate, both ACE and angiotensin II, which are inhibited by RAS inhibitors, seem to function as promoting factors in lung injury, and thus the suggestion of RAS inhibitors as a potential therapy for COVID-19. It has been demonstrated that the coronavirus spike protein binds to ACE2, leading to ACE2 down-regulation, which in turn results in excessive production of angiotensin II, which causes vasoconstriction of lung vessels, increased pulmonary vascular permeability and inflammation, Nonetheless, the lung-protective mechanism is yet to be firmly established in human trials [9].

Major cardiovascular societies have discredited the association of RAS inhibitors and the susceptibility to COVID-19 and encouraged to continue the use of RAS inhibitors in hypertension or other established 
indications [10]. Several observational studies have reported on clinical outcomes among patients with COVID-19 receiving RAS inhibitors [11-20]. In this regard, we review and analysed the data from these studies to examine the link of RAS inhibitors with mortality and disease severity in COVID-19.

\section{METHODS}

Two authors independently performed a systematic literature search in PubMed, and Google Scholar and two preprint servers (medRxiv and SSRN) up to $2^{\text {nd }}$ May 2020. Search terms are depicted inTable S1 . The titles and abstracts of the resulting articles were examined to exclude irrelevant studies. The full texts of the remaining articles were read to determine if these articles meet our eligibility criteria. Bibliographies of retrieved articles were also reviewed for additional studies. The studies eligible for this review reported on exposure to ACEIs/ARBs and the risk of mortality from COVID-19 as well as the severity of COVID19. We also aim to review the definitions of severe/ critical disease used in the included studies. Any discrepancies were addressed by a joint re-evaluation of the original article. Articles were excluded if they did not report mortality risk and severity as two independent outcomes, or without original data. Two authors independently reviewed the primary studies to assess the appropriateness for inclusion and data were extracted. However, studies in the Chinese language were only assessed by CSK (native Chinese). The information extracted from each study is presented in Table 1 .

\section{[Insert Table 1]}

The outcome measures were the risk of mortality and severe/critical disease among patients with and without exposure to ACE inhibitors/ARBs from individual studies. The pooled relative risk (and $95 \%$ confidence interval $[\mathrm{CI}]$ ) of mortality among patients exposed or unexposed to ACEIs/ARBs were calculated using the random-effects model. We also presented the absolute risk difference (reduction) and the number needed to treat to benefit with regards to the exposure to ACEIs/ARBs.

\section{RESULTS}

Our literature search yielded 1,690 unique abstracts. After the removal of duplication and applying the eligibility criteria, 218 relevant articles were examined for further consideration. Of these, 204 studies were excluded mainly for two reasons: no original data and combined mortality and severity endpoint (Figure S1 ). A total of 13 original studies (nine from China, one from Korea, one from the United States, and one multination database) were then included in this review; eleven studies reporting on mortality in ACEI/ARB exposed and unexposed groups and ten studies reporting on disease severity in ACEI/ARB exposed and unexposed groups.

Seven studies, Yang et al. [13], Meng et al. [14], Feng et al. [15], Peng et al. [16], Huang et al. [18], Li et al 20], and Liu et al [21] defined severity of COVID-19 according to Diagnosis and Treatment Protocol for Novel Coronavirus Pneumonia by Chinese National Health Commission. Zeng et al. [19] defined the severity of pneumonia using the guideline for community-acquired pneumonia. Zhang et al. [11] did not classify patients into severe and non-severe cohort but we considered patients with septic shock in the study as having severe/critical COVID-19.

Seven studies were included to calculate pooled relative risk for mortality, absolute risk difference, and number needed to treat to benefit [11,13,14,18-20,23] in COVID-19 patients with hypertension, exposed or unexposed to ACEIs/ARBs (Table 2 ). Lee et al. [12], Peng et al. [16], Chen et al. [17], and Mehra et al. [22] did not segregate the patients based on the presence of hypertension in their studies and therefore were excluded from our pooled analysis to ensure a uniform cohort of hypertensive patients being analysed. The age differences between ACEIs/ARBs and non-ACEIs/ARBs groups were also huge in studies conducted by Lee et al. [12] and Chen et al. [17]. The studies by Feng et al. [15], and Liu et al. [21], did not present mortality data by ACEIs/ARBs use and hence were also excluded from the analysis.

\section{[Insert Table 2]}

On the other hand, seven studies were included to calculate pooled relative risk for severe/critical disease 
[11,13,14,18-21] in COVID-19 patients with hypertension, exposed or unexposed to ACEIs/ARBs (Table 3 ). The studies from Feng et al. [15] and Peng et al. [16] did not segregate the patients based on the presence of hypertension and therefore were excluded from our pooled analysis to ensure a uniform cohort of hypertensive patients being analysed. Moreover, Lee et al. [12], Chen et al. [17], and Mehra et al. [22] did not present data on severity by ACEIs/ARBs use and hence were also excluded from the analysis.

\section{[Insert Table 3]}

Among COVID-19 patients with hypertension, 169 in 871 patients exposed to ACEIs/ARBs, and 430 in 2,041 unexposed to ACEIs/ARBs died with COVID-19. Whereas, 95 in 433 patients exposed to ACEIs/ARBs, and 274 in 1,428 unexposed to ACEIs/ARBs developed a severe/critical COVID-19 disease. The estimated pooled relative risk of mortality and pooled relative risk of disease severity was 0.73 (95\% CI: 0.63-0.86) and 0.72 (95\% CI: 0.46-1.12), respectively (Table 2 \& Table 3 ). The overall absolute risk reduction of mortality associated with ACEI/ARB among COVID-19 patients was 6.7\%. The 'numbers needed to treat to benefit' was 15 , suggesting that every 15 patients exposed to ACIEs/ARBs may prevent an additional death.

\section{DISCUSSION}

This review of original studies aimed to examine the mortality and disease severity in hypertensive COVID-19 patients exposed and unexposed to ACEIs/ARBs. In our analysis, we found a protective effect of ACEI/ARB among hypertensive patients, having a lower risk of mortality. Though we observed no significant difference with regards to disease severity of COVID-19 by the use of ACEI/ARB, there still seems to be a significant protective effect. We believe these results still support the notion that the use of ACEI/ARB is not associated with increased risk of harm in COVID-19 patients but rather a potential protective effect from mortality.

When we look at the individual studies that we included, we found that a significant reduction in the risk of mortality was noted in a study by Zhang et al. [11] when confounders were extensively adjusted with no age difference between the two groups. Zhang et al. [11] included 1,128 patients with hypertension in their study, of which 188 patients were receiving ACEIs/ARBs. They reported that the use of ACEIs/ARBs significantly reduced the risk of all-cause mortality by $58 \%$. The reduction in the mortality risk is even more significant in propensity score-matched analysis where the exposure to RAS Inhibitors was also associated with a $63 \%$ reduced risk of mortality.

Two of the largest studies included in this analysis were by Lee et al. [12] who analysed Korean COVID19 patients $(\mathrm{n}=8,266)$ and Mehra et al. [22] who included COVID-19 patients from 11 countries in Asia, Europe, and North America $(n=8,910)$. Lee et al. [12] did not show any statistical significance even after the adjustment of confounders as in Zhang et. al [11]. Mehra et al. [22] on the other hand, demonstrated a significant reduction in mortality among ACEI users but not ARB users after the adjustment of confounders. This could be due to patients included by Zhang et al. [11] were all hypertensive, compared to only $19.0 \%$ and 26.3\% from Lee et al. [12] and Mehra et al. [22], respectively. Hypertensive patients may have diminished circulatory reserve to meet the excessive demands of COVID-19 on the cardiovascular system and thus a predilection towards cardiac injury and mortality [3]. In this sense, ACEIs/ARBs may have a cardioprotective effect in patients with COVID-19 and thus a reduced risk of mortality as demonstrated in our analysis. Besides, COVID-19 patients with cardiac injury are more likely to be complicated by the acute respiratory distress syndrome (ARDS), in which ACEIs/ARBs may have a protective effect on lung injury due to their effects on angiotensin II as explained above [9].

Likewise, we observed a significant protective effect from severe/critical COVID-19 in hypertensive patients after adjustment of confounders by Zhang et al. [11] where the use of ACEIs/ARBs significantly reduced the risk of severe/critical disease (septic shock) by $64 \%$ and even greater reduction of $68 \%$ in propensity score-matched analysis. However, no benefit was associated with ACEI/ARB use in the development of severe/critical disease in COVID-19 patients with or without hypertension by Feng et al. [15].

Other than a reduced incidence of septic shock, there is also a significant reduction in the risk of disseminated 
intravascular coagulation among hypertensive patients [11]. This is consistent with the anti-inflammatory potential of ACEIs/ARBs, as patients receiving ACEIs/ARBs had also significantly lower concentrations of C-reactive protein and procalcitonin [13]. ACEI/ARB may also protect against cardiac injury as significantly lower levels of cardiac troponin I, N-terminal pro-B-type natriuretic peptide, and lactate dehydrogenase were found in ACEI/ARB users with or without hypertension $[15,18]$. Immunomodulatory function of ACEIs/ARBs have also been reported previously; a significantly higher CD3 and CD8 T-cell counts were found in peripheral blood of hypertensive patients receiving ACEIs/ARBs compared to their counterparts without RAS blockade [14]. There have also been reports of the significant reduction in peak viral load in hypertensive users of ACEI/ARB than the non-users, which to some extent, discredited the suggestion that elevated expression of ACE2 might increase the susceptibility to acquiring SARS-CoV-2 infection or could increase the viral load [14].

In conclusion, this review and analysis of early data demonstrated a protective effect of ACEI/ARB on mortality in COVID-19 patients with hypertension. Moreover, no significant difference was found between ACEI/ARB and non-ACEI/ARB groups in the risk of developing severe/critical COVID-19 disease. Therefore, our analysis with currently available studies should provide comfort to the clinicians who might ponder upon whether to continue the use of ACEI/ARB in hypertensive patients amid the COVID-19 pandemic.

Funding : This study was not funded.

Conflict of interest statement : The authors have no conflict of interest to declare.

\section{Author contributions:}

S.S.-H., and C.S.-K. conceptualized the review.

S.S.-H., C.S.-K, and H.A.-M. were involved in the searching, data extraction, analysis, and interpretation of the data.

All authors were involved in drafting the article.

All authors critically reviewed and approved the final version of the manuscript.

Data availability statement: All associated data are presented in the article and supplementary file

\section{REFERENCES}

1. Guan WJ, Ni ZY, Hu Y, et al. Clinical characteristics of coronavirus disease 2019 in China [published online ahead of print, 2020 Feb 28]. N Engl J Med. 2020;10.1056/NEJMoa2002032.

2. Zhang JJ, Dong X, Cao YY, et al. Clinical characteristics of 140 patients infected with SARS-CoV-2 in Wuhan, China [published online ahead of print, 2020 Feb 19]. Allergy. 2020;10.1111/all.14238.

3. Shi S, Qin M, Shen B, et al. Association of cardiac injury with mortality in hospitalized patients with COVID-19 in Wuhan, China [published online ahead of print, 2020 Mar 25]. JAMA Cardiol. 2020;e200950.

4. Fang L, Karakiulakis G, Roth M. Are patients with hypertension and diabetes mellitus at increased risk for COVID-19 infection? [published online ahead of print, 2020 Mar 11]. Lancet Respir Med. 2020;S2213-2600(20)30116-8.

5. Zhou P, Yang XL, Wang XG, et al. A pneumonia outbreak associated with a new coronavirus of probable bat origin. Nature. 2020;579(7798):270-273.

6. Ishiyama Y, Gallagher PE, Averill DB, Tallant EA, Brosnihan KB, Ferrario CM. Upregulation of angiotensin-converting enzyme 2 after myocardial infarction by blockade of angiotensin II receptors. Hypertension. 2004;43(5):970-976.

7. Ocaranza MP, Godoy I, Jalil JE, et al. Enalapril attenuates downregulation of Angiotensin-converting enzyme 2 in the late phase of ventricular dysfunction in myocardial infarcted rat. Hypertension. 2006; $48(4): 572-578$.

8. Hristova M, Stanilova S, Miteva L. Serum concentration of renin-angiotensin system components in association with ACE I/D polymorphism among hypertensive subjects in response to ACE inhibitor 
therapy. Clin Exp Hypertens. 2019;41(7):662-669.

9. Kuba K, Imai Y, Rao S, et al. A crucial role of angiotensin-converting enzyme 2 (ACE2) in SARS coronavirus-induced lung injury. Nat Med. 2005;11(8):875-879.

10. Kow CS, Zaidi STR, Hasan SS. Cardiovascular Disease and Use of Renin-Angiotensin System Inhibitors in COVID-19 [published online ahead of print, 2020 Apr 13]. Am J Cardiovasc Drugs. 2020;10.1007/s40256-020-00406-0.

11. Zhang P, Zhu L, Cai J, et al. Association of Inpatient Use of Angiotensin-Converting Enzyme Inhibitors and Angiotensin II Receptor Blockers with Mortality Among Patients With Hypertension Hospitalized With COVID-19 [published online ahead of print, 2020 Apr 17]. Circ Res. 2020;10.1161/CIRCRESAHA.120.317134.

12. Lee H, Ahn J, Kang CK, et al. Association of angiotensin II receptor blockers and angiotensinconverting enzyme inhibitors on COVID-19-related outcome. 2020. Available at SSRN: https://ssrn.com/abstract $=3569837$ (21 April 2020)

13. Yang G, Tan Z, Zhou L, et al. Effects Of ARBs And ACEIs On Virus Infection, Inflammatory Status And Clinical Outcomes In COVID-19 Patients With Hypertension: A Single Center Retrospective Study [published online ahead of print, 2020 Apr 29]. Hypertension. 2020;10.1161/HYPERTENSIONAHA.120.15143.

14. Meng J, Xiao G, Zhang J, et al. Renin-angiotensin system inhibitors improve the clinical outcomes of COVID-19 patients with hypertension. Emerg Microbes Infect. 2020;9(1):757-760.

15. Feng Z, Li J, Yao S, et al. The use of adjuvant therapy in preventing progression to severe pneumonia in patients with coronavirus disease 2019: a multicenter data analysis. 2020. medRxiv 2020.04.08.20057539

16. Peng YD, Meng K, Guan HQ, et al. Clinical features and outcome of 112 cases of novel coronavirus pneumonia in cardiovascular patients [Chinese]. Chin. J. Cardiol. 2020;48.

17. Chen M, Fan Y, Wu X, et al. Clinical Characteristics And Risk Factors For Fatal Outcome in Patients With 2019-Coronavirus Infected Disease (COVID-19) in Wuhan, China. 2020. Available at SSRN: https://ssrn.com/abstract $=3546069$ (21 April 2020)

18. Huang Z, Cao J, Yao Y, et al. The effect of RAS blockers on the clinical characteristics of COVID-19 patients with hypertension. Ann Transl Med. 2020;8(7):430.

19. Zeng Z, Sha T, Zhang Y et al. Hypertension in patients hospitalized with COVID-19 in Wuhan, China: a single-center retrospective observational study. medRxiv 2020.04.06.20054825

20. Li J, Wang X, Chen J, Zhang H, Deng A. Association of Renin-Angiotensin System Inhibitors With Severity or Risk of Death in Patients With Hypertension Hospitalized for Coronavirus Disease 2019 (COVID-19) Infection in Wuhan, China [published online ahead of print, 2020 Apr 23]. JAMA Cardiol. 2020;10.1001/jamacardio.2020.1624.

21. Liu Y, Huang F, Xu J, et al. Anti-hypertensive Angiotensin II receptor blockers associated to mitigation of disease severity in elderly COVID-19 patients. medRxiv 2020.03.20.20039586

22. Mehra MR, Desai SS, Kuy S, Henry TD, Patel AN. Cardiovascular Disease, Drug Therapy, and Mortality in Covid-19 [published online ahead of print, 2020 May 1]. N Engl J Med. 2020;10.1056/NEJMoa2007621.

23. Ip A, Parikh K, Parrillo JE, et al. Hypertension and Renin-Angiotensin-Aldosterone System Inhibitors in Patients with Covid-19. medRxiv 2020.04.24.20077388

Table 1: Summary of studies examining the mortality and critical/severe disease in ACE inhibitor/ARB exposed and unexposed groups

\begin{tabular}{|c|c|c|c|c|c|c|c|}
\hline Study & $\begin{array}{l}\text { Study } \\
\text { type }\end{array}$ & Origin & $\begin{array}{l}\text { Total no. } \\
\text { of } \\
\text { patients }\end{array}$ & $\begin{array}{l}\text { Median } \\
\text { Age } \\
\text { (years) }\end{array}$ & $\begin{array}{l}\text { Proportion } \\
\text { of hyper- } \\
\text { tension }\end{array}$ & Mortality & $\begin{array}{l}\text { Critical/Sev } \\
\text { disease }^{1}\end{array}$ \\
\hline & & & & & & $\begin{array}{l}\text { Adjusted } \\
\text { Estimate }\end{array}$ & $\begin{array}{l}\text { Adjusted } \\
\text { Estimate }\end{array}$ \\
\hline
\end{tabular}




\begin{tabular}{|c|c|c|c|c|c|c|c|}
\hline Study & $\begin{array}{l}\text { Study } \\
\text { type }\end{array}$ & Origin & $\begin{array}{l}\text { Total no. } \\
\text { of } \\
\text { patients }\end{array}$ & $\begin{array}{l}\text { Median } \\
\text { Age } \\
\text { (years) }\end{array}$ & $\begin{array}{l}\text { Proportion } \\
\text { of hyper- } \\
\text { tension }\end{array}$ & Mortality & $\begin{array}{l}\text { Critical/Seve } \\
\text { disease }^{1}\end{array}$ \\
\hline $\begin{array}{l}\text { Zhang et } \\
\text { al }[11]\end{array}$ & $\begin{array}{l}\text { Retrospective, } \\
\text { multicentre }\end{array}$ & $\begin{array}{l}\text { Hubei, } \\
\text { China }\end{array}$ & 1,128 & \multicolumn{2}{|c|}{$\begin{array}{l}\text { ACEI } / A R B=64100 \\
\& \text { Non- } \\
\text { ACEI } / A R B=64\end{array}$} & $\begin{array}{l}\mathrm{HR}=0.37 \\
(0.15-0.89)\end{array}$ & $\begin{array}{l}\mathrm{HR}=0.32 \\
(0.13-0.80)\end{array}$ \\
\hline $\begin{array}{l}\text { Lee et } \\
\mathrm{al}^{2}[12]\end{array}$ & $\begin{array}{l}\text { Retrospective } \\
\text { database } \\
\text { review }\end{array}$ & Korea & 8,266 & \multicolumn{2}{|c|}{$\begin{array}{l}\text { ACEI } / \mathrm{ARB}=6719.0 \\
\& \text { Non- } \\
\text { ACEI } / \mathrm{ARB}=42\end{array}$} & $\begin{array}{l}\mathrm{HR}=1.07 \\
(0.68-1.65)\end{array}$ & - \\
\hline $\begin{array}{l}\text { Yang et } \\
\text { al [13] }\end{array}$ & $\begin{array}{l}\text { Retrospective, } \\
\text { single } \\
\text { centre }\end{array}$ & $\begin{array}{l}\text { Hubei, } \\
\text { China }\end{array}$ & 251 & \multicolumn{2}{|c|}{$\begin{array}{l}\text { ACEI } / \mathrm{ARB}=65100 \\
\& \text { Non- } \\
\mathrm{ACEI} / \mathrm{ARB}=67\end{array}$} & - & - \\
\hline $\begin{array}{l}\text { Meng et } \\
\text { al }[14]\end{array}$ & $\begin{array}{l}\text { Retrospective, } \\
\text { single } \\
\text { centre }\end{array}$ & $\begin{array}{l}\text { Shenzhen, } \\
\text { China }\end{array}$ & 42 & \multicolumn{2}{|c|}{$\begin{array}{l}\text { ACEI/ARB }=64100 \\
\& \text { Non- } \\
\text { ACEI/ARB } \\
=65\end{array}$} & - & - \\
\hline $\begin{array}{l}\text { Feng et } \\
\mathrm{al}^{2}[15]\end{array}$ & $\begin{array}{l}\text { Retrospective, } \\
\text { multicentre }\end{array}$ & China & 65 & \multicolumn{2}{|c|}{$\begin{array}{l}\text { ACEI } / \mathrm{ARB}=5714.5 \\
\& \text { Non- } \\
\text { ACEI/ARB }=63\end{array}$} & - & $\begin{array}{l}\mathrm{OR}=0.41 \\
(0.05-3.19)\end{array}$ \\
\hline $\begin{array}{l}\text { Peng et al } \\
{[16]}\end{array}$ & $\begin{array}{l}\text { Retrospective, } \\
\text { single centre }\end{array}$ & $\begin{array}{l}\text { Wuhan, } \\
\text { China }\end{array}$ & 112 & \multicolumn{2}{|l|}{ Severe $=57.5$} & - & - \\
\hline $\begin{array}{l}\text { Chen et } \\
\mathrm{al}^{2}[17]\end{array}$ & $\begin{array}{l}\text { Retrospective, } \\
\text { single } \\
\text { centre }\end{array}$ & $\begin{array}{l}\text { Wuhan, } \\
\text { China }\end{array}$ & 123 & \multicolumn{2}{|c|}{$\begin{array}{l}\text { Discharged=53 } 33.3 \\
\& \\
\text { Death }=72\end{array}$} & - & - \\
\hline $\begin{array}{l}\text { Huang et } \\
\text { al [18] }\end{array}$ & $\begin{array}{l}\text { Retrospective, } \\
\text { single } \\
\text { centre }\end{array}$ & $\begin{array}{l}\text { Wuhan, } \\
\text { China }\end{array}$ & 50 & \multicolumn{2}{|c|}{$\begin{array}{l}\text { ACEI } / \mathrm{ARB}=53100 \\
\& \text { Non- } \\
\text { ACEI } / \mathrm{ARB}=68\end{array}$} & - & - \\
\hline $\begin{array}{l}\text { Zeng et } \\
\mathrm{al}^{2}[19]\end{array}$ & $\begin{array}{l}\text { Retrospective, } \\
\text { single } \\
\text { centre }\end{array}$ & $\begin{array}{l}\text { Wuhan, } \\
\text { China }\end{array}$ & 274 & \multicolumn{2}{|c|}{$\begin{array}{l}\text { ACEI } / \mathrm{ARB}=6427.3 \\
\& \text { Non- } \\
\text { ACEI } / \mathrm{ARB}=69\end{array}$} & - & - \\
\hline Li et al 20] & $\begin{array}{l}\text { Retrospective, } \\
\text { Single centre }\end{array}$ & $\begin{array}{l}\text { Wuhan, } \\
\text { China }\end{array}$ & 362 & \multicolumn{2}{|c|}{$\begin{array}{l}\mathrm{ACEI} / \mathrm{ARB}=65100 \\
\& \text { Non- } \\
\mathrm{ACEI} / \mathrm{ARB}=67\end{array}$} & - & - \\
\hline $\begin{array}{l}\text { Liu et al } \\
{[21]}\end{array}$ & $\begin{array}{l}\text { Retrospective, } \\
\text { Multi } \\
\text { centre }\end{array}$ & China & 78 & \multicolumn{2}{|c|}{$\begin{array}{l}\text { ACEI/ARB }>65100 \\
\& \text { Non- } \\
\text { ACEI/ARB }>65\end{array}$} & - & \\
\hline $\begin{array}{l}\text { Mehra et } \\
\text { al [22] }\end{array}$ & $\begin{array}{l}\text { Observational } \\
\text { database }\end{array}$ & $\begin{array}{l}\text { Asia, } \\
\text { Europe and } \\
\text { North } \\
\text { America }\end{array}$ & 8,910 & $\begin{array}{l}\text { ACEI/ARB } \\
\& \text { Non- } \\
\text { ACEI/ARB = } \\
49\end{array}$ & 26.3 & $\begin{array}{l}\text { OR= ACEI: } \\
0.33 \\
(0.20-0.54) \\
\text { ARB: } 1.23 \\
(0.87-1.74)\end{array}$ & - \\
\hline $\begin{array}{l}\text { Ip et } \mathrm{al}^{2} \\
{[23]}\end{array}$ & $\begin{array}{l}\text { Retrospective, } \\
\text { multicentre }\end{array}$ & $\begin{array}{l}\text { New } \\
\text { Jersey, } \\
\text { USA }\end{array}$ & 1129 & - & 100 & - & - \\
\hline
\end{tabular}

$\mathrm{ACEI}=$ angiotensin-converting enzyme inhibitor; $\mathrm{ARB}=$ angiotensin receptor blocker; $\mathrm{COPD}=$ chronic obstructive pulmonary disease; $\mathrm{HR}=$ hazard ratio; $\mathrm{OR}=$ odds ratio $^{1}$ The definition of severe/critical disease in Yang et al., Meng et al., Feng et al., Peng et al., and Liu et al. was based on the definition given in Diagnosis and Treatment Protocol for Novel Coronavirus Pneumonia by Chinese National Health Commission; in Zhang et. al was defined based on the presence of septic shock, and in Zeng et. al was based on the guideline 
for community-acquired pneumonia. ${ }^{2}$ Preprints which are yet to undergo peer-review at the time of writing.

Table 2 : Absolute risk reduction and relative risk for mortality in ACEI/ARB exposed and unexposed hypertensive patients

\begin{tabular}{|c|c|c|c|c|c|c|c|c|}
\hline Study & $\begin{array}{l}\text { Exposure } \\
\text { to } \\
\text { ACEI/ARB }\end{array}$ & $\begin{array}{l}\text { Exposure } \\
\text { to } \\
\text { ACEI/ARB }\end{array}$ & $\begin{array}{l}\text { Exposure } \\
\text { to } \\
\text { ACEI/ARB }\end{array}$ & $\begin{array}{l}\text { No } \\
\text { Exposure } \\
\text { to } \\
\text { ACEI/ARB }\end{array}$ & $\begin{array}{l}\text { No } \\
\text { Exposure } \\
\text { to } \\
\text { ACEI/ARB }\end{array}$ & $\begin{array}{l}\text { No } \\
\text { Exposure } \\
\text { to } \\
\text { ACEI/ARB }\end{array}$ & ARR (\%) & NNTB \\
\hline & Total & $\begin{array}{l}\text { Mortality } \\
\text { Cases }\end{array}$ & $\begin{array}{l}\text { Non- } \\
\text { mortality } \\
\text { Cases }\end{array}$ & Total & $\begin{array}{l}\text { Mortality } \\
\text { Cases }\end{array}$ & $\begin{array}{l}\text { Non- } \\
\text { mortality } \\
\text { Cases }\end{array}$ & & \\
\hline $\begin{array}{l}\text { Zhang et } \\
\text { al., China } \\
\text { [11] }\end{array}$ & 188 & 7 & 181 & 940 & 92 & 848 & 6.10 & 16 \\
\hline $\begin{array}{l}\text { Yang et } \\
\text { al., China } \\
{[13]}\end{array}$ & 43 & 2 & 41 & 83 & 11 & 72 & 8.60 & 12 \\
\hline $\begin{array}{l}\text { Meng et } \\
\text { al., China } \\
{[14]}\end{array}$ & 17 & 0 & 17 & 25 & 1 & 24 & 4.00 & 25 \\
\hline $\begin{array}{l}\text { Huang et } \\
\text { al., China } \\
{[18]}\end{array}$ & 20 & 0 & 20 & 30 & 3 & 27 & 10.00 & 11 \\
\hline $\begin{array}{l}\text { Zeng et } \\
\text { al., China } \\
{[19]^{1}}\end{array}$ & 28 & 2 & 26 & 47 & 5 & 42 & 3.50 & 29 \\
\hline $\begin{array}{l}\text { Li et al., } \\
\text { China }[20]\end{array}$ & 115 & 21 & 94 & 247 & 56 & 191 & 4.40 & 23 \\
\hline $\begin{array}{l}\text { Ip et al., } \\
\text { USA }[23]^{1}\end{array}$ & 460 & 137 & 323 & 669 & 262 & 407 & 9.40 & 11 \\
\hline $\begin{array}{l}\text { Total/Pooled } \\
\text { statistics }\end{array}$ & 871 & 169 & 702 & 2041 & 430 & 1611 & 6.70 & 15 \\
\hline
\end{tabular}

$\mathrm{ACEI}=$ angiotensin-converting enzyme inhibitor; $\mathrm{ARB}=$ angiotensin receptor blocker; $\mathrm{ARR}=\mathrm{absolute}$ risk reduction; $\mathrm{NNTB}=$ number needed to treat to benefit; $\mathrm{RR}=$ relative risk

${ }^{1}$ Preprints which are yet to undergo peer-review at the time of writing.

Table 3 : Relative risk for critical/severe disease in ACEI/ARB exposed and unexposed hypertensive patients

\begin{tabular}{|c|c|c|c|c|c|c|c|c|}
\hline Study & $\begin{array}{l}\text { Exposure } \\
\text { to } \\
\text { ACEI/ARB }\end{array}$ & $\begin{array}{l}\text { Exposure } \\
\text { to } \\
\text { ACEI/ARB }\end{array}$ & $\begin{array}{l}\text { Exposure } \\
\text { to } \\
\text { ACEI/ARB }\end{array}$ & $\begin{array}{l}\text { No Ex- } \\
\text { posure } \\
\text { to } \\
\text { ACEI/ARB }\end{array}$ & $\begin{array}{l}\text { No Ex- } \\
\text { posure } \\
\text { to } \\
\text { ACEI/ARB }\end{array}$ & $\begin{array}{l}\text { No Ex- } \\
\text { posure } \\
\text { to } \\
\text { ACEI/ARB }\end{array}$ & $\begin{array}{l}\text { ARR } \\
(\%)\end{array}$ & NNT \\
\hline & Total & $\begin{array}{l}\text { Critical/Se } \\
\text { Cases }\end{array}$ & $\begin{array}{l}\text { vidicen- } \\
\text { critical/- } \\
\text { severe } \\
\text { cases }\end{array}$ & Total & $\begin{array}{l}\text { Critical/Se } \\
\text { Cases }\end{array}$ & $\begin{array}{l}\text { vicion- } \\
\text { critical/- } \\
\text { severe } \\
\text { cases }\end{array}$ & & \\
\hline
\end{tabular}




\begin{tabular}{|c|c|c|c|c|c|c|c|c|}
\hline Study & $\begin{array}{l}\text { Exposure } \\
\text { to } \\
\mathrm{ACEI} / \mathrm{ARB}\end{array}$ & $\begin{array}{l}\text { Exposure } \\
\text { to } \\
\mathrm{ACEI} / \mathrm{ARB}\end{array}$ & $\begin{array}{l}\text { Exposure } \\
\text { to } \\
\text { ACEI/ARB }\end{array}$ & $\begin{array}{l}\text { No Ex- } \\
\text { posure } \\
\text { to } \\
\text { ACEI/ARB }\end{array}$ & $\begin{array}{l}\text { No Ex- } \\
\text { posure } \\
\text { to } \\
\text { ACEI/ARB }\end{array}$ & $\begin{array}{l}\text { No Ex- } \\
\text { posure } \\
\text { to } \\
\text { ACEI/ARB }\end{array}$ & $\begin{array}{l}\text { ARR } \\
(\%) \\
\end{array}$ & NNT \\
\hline $\begin{array}{l}\text { Zhang et } \\
\text { al., China } \\
{[11]}\end{array}$ & 188 & 6 & 182 & 940 & 75 & 865 & 4.80 & 21 \\
\hline $\begin{array}{l}\text { Yang et } \\
\text { al., China } \\
{[13]}\end{array}$ & 43 & 4 & 39 & 83 & 19 & 64 & 13.60 & 7 \\
\hline $\begin{array}{l}\text { Meng et } \\
\text { al., China } \\
{[14]}\end{array}$ & 17 & 4 & 13 & 25 & 12 & 13 & 24.50 & 4 \\
\hline $\begin{array}{l}\text { Huang et } \\
\text { al., China } \\
{[18]}\end{array}$ & 20 & 2 & 18 & 30 & 6 & 24 & 10.00 & 10 \\
\hline $\begin{array}{l}\text { Zeng et } \\
\text { al., China } \\
{[19]^{1}}\end{array}$ & 28 & 15 & 13 & 47 & 15 & 32 & +21.70 & 5 \\
\hline $\begin{array}{l}\text { Li et al., } \\
\text { China }[20]\end{array}$ & 115 & 57 & 58 & 247 & 116 & 131 & +2.60 & 38 \\
\hline $\begin{array}{l}\text { Liu et al., } \\
\text { China } \\
{[21]^{1}}\end{array}$ & 22 & 7 & 15 & 56 & 31 & 25 & 23.50 & 4 \\
\hline $\begin{array}{l}\text { Total/Pooled } \\
\text { statistics }\end{array}$ & 433 & 95 & 338 & 1428 & 274 & 1154 & 6.00 & 17 \\
\hline
\end{tabular}

$\mathrm{ACEI}=$ angiotensin-converting enzyme inhibitor; $\mathrm{ARB}=$ angiotensin receptor blocker; $\mathrm{ARD}=$ absolute risk difference; $\mathrm{RR}=$ relative risk; $+=$ absolute risk increase

${ }^{1}$ Preprints which are yet to undergo peer-review at the time of writing. 